Provided for non-commercial research and education use. Not for reproduction, distribution or commercial use.
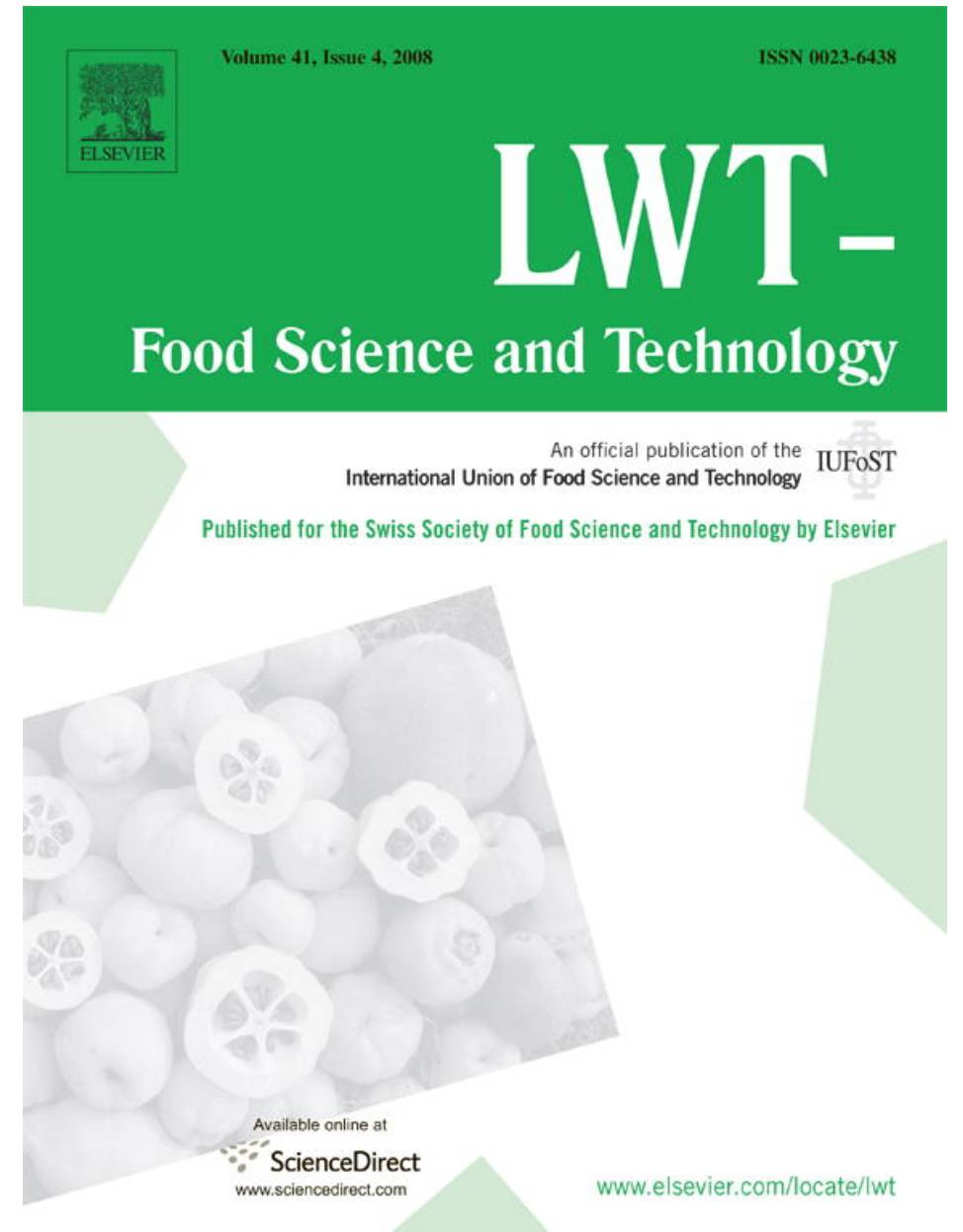

This article was published in an Elsevier journal. The attached copy

is furnished to the author for non-commercial research and education use, including for instruction at the author's institution, sharing with colleagues and providing to institution administration.

Other uses, including reproduction and distribution, or selling or licensing copies, or posting to personal, institutional or third party websites are prohibited.

In most cases authors are permitted to post their version of the article (e.g. in Word or Tex form) to their personal website or institutional repository. Authors requiring further information regarding Elsevier's archiving and manuscript policies are encouraged to visit:

http://www.elsevier.com/copyright 


\title{
Effect of solvent and extraction temperatures on the antioxidant potential of traditional stoned table olives "alcaparras"
}

\author{
Anabela Sousa, I.C.F.R. Ferreira, Lillian Barros, Albino Bento, José Alberto Pereira* \\ CIMO/Escola Superior Agrária, Instituto Politécnico de Bragança, Campus de Sta Apolónia, Apartado 1172, 5301-855 Bragança, Portugal
}

Received 16 August 2006; received in revised form 3 April 2007; accepted 5 April 2007

\begin{abstract}
This paper reports the first approach to the antioxidant potential evaluation of traditional stoned table olives "alcaparras". This kind of olives are largely produced and consumed in Trás-os-Montes region (Northeast of Portugal). Different solvents and temperature extraction conditions were employed in order to achieve the best method to obtain phenolic compounds and a higher antioxidant activity. The optimum method (water at boiling temperature) was applied on 10 samples from the traditional market. The total phenol content ranged between $5.58 \mathrm{mg}$ gallic acid equivalents $(\mathrm{GAE}) / \mathrm{g}$ and $29.88 \mathrm{mg} \mathrm{GAE} / \mathrm{g}$ and effective concentration $\left(\mathrm{EC}_{50}\right)$ values were in the range $0.36-1.64$ and $0.34-1.72 \mathrm{mg} / \mathrm{mL}$ for reducing power and radical scavenging effect, respectively. A significantly negative linear regression was observed between the total phenol content found in the samples and its antioxidant activity.

(C) 2007 Swiss Society of Food Science and Technology. Published by Elsevier Ltd. All rights reserved.
\end{abstract}

Keywords: Stoned table olives; Extraction conditions; Phenols; Antioxidant potential

\section{Introduction}

Mediterranean diet has been associated with a lower risk of coronary heart disease and certain kinds of cancer, e.g. breast and colon cancers (Keys, 1995; Trichopoulou \& Lagiou, 1997). This diet is rich in fruits, vegetables, whole grains, fish, low-fat dairy products and monounsaturated fats (Panagiotakos, Pitsavos, \& Stefanadis, 2006). In this diet, olive oil is the main source of fat, in daily cooked dishes and salads, and table olives are also largely consumed.

According to the Trade Standard Applying to Table Olives (COI/OT/NC no. 1, 2004) table olives are defined as the product "prepared from the sound fruits of varieties of the cultivated olive tree (Olea europaea L.) that are chosen for their production of olives whose volume, shape, fleshto-stone ratio, fine flesh, taste, firmness and ease of detachment from the stone make them particularly suitable for processing". Different kinds of table olives should be classified according to the ripeness stage of the fruit, trade preparation, styles and sizing. Stoned halved olives are one

\footnotetext{
${ }^{*}$ Corresponding author. Tel.: + 351273303277 ; fax: +351273325405.

E-mail address: jpereira@ipb.pt (J.A. Pereira).
}

of the styles considered by the Trade Standard already referred.

In the Northeast of Portugal, stoned halved olives known as "alcaparras" are largely produced by the local growers, commercialized in the local market and consumed flavoured with herb spices, onion, garlic, vinegar and olive oil. "Alcaparras" are processed from green or yellow-green healthy olive fruits, which are broken using a wood hammer, being the pulp and stone separated. The pulp is sliced into two approximately equal parts, perpendicularly to the major axis of the fruit, and placed in water, which is changed three or four times during a week. This treatment removes the bitterness and the olives can be salted, flavoured and consumed.

In the past few years, the suspected toxicity of some synthetic compounds used in food has raised the interest in natural products (Fukushima \& Tsuda, 1985; Stone, Leclair, Ponder, Bagss, \& Barret-Reis, 2003). Some industries, such as those related to food additive production, cosmetics, and pharmaceuticals, have increased their efforts in obtaining bioactive compounds from natural products by extraction and purification. Antioxidant compounds can increase shelf life by retarding the process 
of lipid peroxidation, which is one of the major reasons for deterioration of food products during processing and storage (Halliwell, 1997; Halliwell \& Gutteridge, 1999).

There is an increasing interest in olive products and byproducts, due to their antimicrobial and antioxidant properties. Recently our research group demonstrated a strong antimicrobial activity of "alcaparras" extracts against several microorganisms that may be causal agents of human intestinal and respiratory tract infections (Sousa et al., 2006). Concerning to the antioxidant activity, olive oil polyphenols revealed good properties (Gordon, PaivaMartins, \& Almeida, 2001; Paiva-Martins, Gordon, \& Gameiro, 2003) and olive leaves have been referred as a source of several antioxidants (Briante et al., 2002; Bouaziz \& Sayadi, 2005; Meirinhos et al., 2005; Ranalli et al., 2006; Ferreira, Barros, Soares, Bastos, \& Pereira, 2007). Also table olives have been studied in its polyphenol composition (Marsilio, Campestre, \& Lanza, 2001; Blekas, Vassilakis, Harizanis, Tsimidou, \& Boskou, 2002; Romero, García, Brenes, García, \& Garrido, 2002; Romero et al., 2004; Pereira et al., 2006) and antioxidant activity (Owen et al., 2003; Boskou et al., 2006; Pereira et al., 2006). Nevertheless, as far as we know, it is the first time that a study on the antioxidant potential of stoned table olives "alcaparras" is reported.

Herein, we intended to find the most appropriate solvent for extracting phenols, in relation to other constituents, from "alcaparras" table olives and to correlate their levels with antioxidant activity of the extracts obtained. The best extraction method was applied to 10 samples from the tradition market of four different municipalities of Trás-osMontes region, and their reducing power and scavenging effect on DPPH (2,2-diphenyl-1-picrylhydrazyl) radicals were investigated and correlated with their total phenolic content.

\section{Materials and methods}

\subsection{Samples}

Ten different samples of stoned table olives "alcaparras" were obtained in the traditional market. The samples were from different municipalities of Trás-os-Montes region: Bragança (samples B1-B5), Mirandela (M1 and M2), Carrazeda de Ansiães (CA1 and CA2) and Macedo de Cavaleiros (MC).

\subsection{Standards and reagents}

BHA (2-tert-butyl-4-methoxyphenol), $\alpha$-tocopherol and gallic acid were purchased from Sigma (St. Louis, MO, USA). DPPH was obtained from Alfa Aesar (Ward Hill, MA, USA). All other chemicals were obtained from Sigma Chemical Co. (St. Louis, USA). Methanol was obtained from Pronalab (Lisboa, Portugal). Water was treated in a Milli-Q water purification system (TGI Pure Water Systems, USA).

\subsection{Sample preparation}

The samples $(\sim 100 \mathrm{~g})$ were dried in a stove (Memmert Schwabach 854,1994$)$ at $30^{\circ} \mathrm{C}$ for three days and stored at $4{ }^{\circ} \mathrm{C}$ protected from light until further use.

For the extraction method optimization, a fine dried powder (20 mesh) of sample B1 (5g) was extracted using four different conditions:

(i) Extraction with $250 \mathrm{~mL}$ of boiling water (bt) for $45 \mathrm{~min}$ and filtered through Whatman no. 4 paper. The aqueous extract was frozen and lyophilized.

(ii) Stirring with $100 \mathrm{~mL}$ of water at room temperature (rt) at $150 \mathrm{rpm}$ for $24 \mathrm{~h}$ and filtered through Whatman no. 4 paper. The residue was then extracted with two additional $100 \mathrm{~mL}$ portions of water, as described earlier. The combined aqueous extracts were frozen and lyophilized.

(iii) Extraction using a Soxhlet extractor for $8 \mathrm{~h}$ with $250 \mathrm{~mL}$ of methanol $(\mathrm{MeOH})$. The methanolic extract was evaporated at $40{ }^{\circ} \mathrm{C}$ to dryness.

(iv) Stirring with $100 \mathrm{~mL}$ of methanol at $\mathrm{rt}$ at $150 \mathrm{rpm}$ for $24 \mathrm{~h}$ and filtered through Whatman no. 4 paper. The residue was then extracted with two additional $100 \mathrm{~mL}$ portions of methanol, as described earlier. The combined methanolic extracts were evaporated at $40{ }^{\circ} \mathrm{C}$ to dryness.

All the extracts were redissolved in the corresponding solvent at a concentration of $50 \mathrm{mg} / \mathrm{mL}$, and analysed for their content in phenols.

The first extraction method was employed in the preparation of 10 different samples for analysis of their antioxidant activity.

\subsection{Determination of total phenol content}

Phenolic compounds concentration in the extracts was estimated by a colorimetric assay based on procedures described by Singleton and Rossi (1965) with some modifications. Briefly, $1 \mathrm{~mL}$ of sample was mixed with $1 \mathrm{~mL}$ of Folin and Ciocalteu's phenol reagent. After $3 \mathrm{~min}$, $1 \mathrm{~mL}$ of saturated $\mathrm{Na}_{2} \mathrm{CO}_{3}$ solution was added to the mixture and adjusted to $10 \mathrm{~mL}$ with distilled water. The reaction was kept in the dark for $90 \mathrm{~min}$, after which the absorbance was read at $725 \mathrm{~nm}$ (Analytik Jena 2000-2004 spectrophotometer). Gallic acid was used for constructing the standard curve $(0.01-0.4 \mathrm{mM})$. The results are expressed as $\mathrm{mg}$ of gallic acid equivalents/g of extract (GAEs).

\subsection{Reducing power assay}

The reducing power was determined according to the method of Oyaizu (1986). The extract solution $(2.5 \mathrm{~mL})$ was mixed with $2.5 \mathrm{~mL}$ of $200 \mathrm{mmol} / \mathrm{L}$ sodium phosphate buffer ( $\mathrm{pH} 6.6)$ and $2.5 \mathrm{~mL}$ of $1 \%$ potassium ferricyanide. 
The mixture was incubated at $50{ }^{\circ} \mathrm{C}$ for $20 \mathrm{~min}$. After $2.5 \mathrm{~mL}$ of $10 \%$ trichloroacetic acid (w/v) were added, the mixture was centrifuged at $1000 \mathrm{rpm}$ for $8 \mathrm{~min}$ (Centorion K24OR-2003 refrigerated centrifuge). The upper layer $(5 \mathrm{~mL})$ was mixed with $5 \mathrm{~mL}$ of deionized water and $1 \mathrm{~mL}$ of $0.1 \%$ of ferric chloride, and the absorbance was measured spectrophotometrically at $700 \mathrm{~nm}$ (higher absorbance indicates higher reducing power). Extract concentration providing 0.5 of absorbance $\left(\mathrm{EC}_{50}\right)$ was calculated from the graph of absorbance at $700 \mathrm{~nm}$ against extract concentration in the solution. BHA and $\alpha$-tocopherol methanolic solutions were used as standards.

\subsection{Scavenging effect assay}

The capacity to scavenge the "stable" free radical DPPH was monitored according to the method of Hatano, Kagawa, Yasuhara, and Okuda (1988). The extract solution $(0.3 \mathrm{~mL})$ was mixed with $2.7 \mathrm{~mL}$ of methanolic solution containing DPPH radicals $\left(6 \times 10^{-5} \mathrm{~mol} / \mathrm{L}\right)$. The mixture was shaken vigorously and left to stand for $60 \mathrm{~min}$ in the dark (until stable absorbance values were obtained). The reduction of the DPPH-radical was measured by continuous monitoring of the decrease of absorption at $517 \mathrm{~nm}$. DPPH scavenging effect was calculated as a percentage of DPPH discolouration using the equation: $\%$ scavenging effect $=\left[\left(A_{\mathrm{DPPH}}-A_{\mathrm{S}}\right) / A_{\mathrm{DPPH}}\right] \times 100$, where $A_{\mathrm{S}}$ is the absorbance of the solution when the sample extract has been added at a particular level, and $A_{\mathrm{DPPH}}$ is the absorbance of the DPPH solution. The extract concentration providing $50 \%$ inhibition $\left(\mathrm{EC}_{50}\right)$ was calculated from the graph of scavenging effect percentage against extract concentration in the solution. BHA and $\alpha$ tocopherol methanolic solutions were used as standards.

\subsection{Statistical analysis}

For each extraction method conditions, nine assays were performed using the sample B1. The differences between treatments (solvent and temperature conditions) in each parameter were analysed using one-way analysis of variance (ANOVA) followed by Tukey's HSD Test with $\alpha=0.05$. This treatment was carried out using SAS v. 9.1.3 program. All the antioxidant activity assays were carried out in triplicate and the results are shown as mean values and standard deviation. The regression analysis between phenol contents and $\mathrm{EC}_{50}$ values for reducing power and scavenging activity was conducted using the same statistical package.

\section{Results and discussion}

\subsection{Influence of the extraction conditions in the "alcaparras" antioxidant potential}

In order to achieve the best extraction conditions, the total phenol content, reducing power and DPPH radical scavenging activity were evaluated for the stoned table olives "alcaparras" (sample B1) obtained using two different extraction solvents (water and methanol) and two different temperatures (room and boiling temperatures) (Table 1).

In this study, using methanol as solvent no significant differences $(p>0.05)$ were observed either in $\mathrm{rt}$ or in boiling temperature. The total phenol content and the $\mathrm{EC}_{50}$ values for reducing power and scavenging activity obtained after table olive sample extraction at both temperatures were very similar. However, a higher reproducibility of the results was observed in the case of extraction at $\mathrm{rt}$ (lower standard deviation values).

The extraction procedure using water at $\mathrm{rt}$ was significantly $(p<0.05)$ least efficient (very low total phenol content, $3.48 \mathrm{mg} / \mathrm{g}$ dry extract, and higher $\mathrm{EC}_{50}$ values, $4.21 \mathrm{mg} / \mathrm{mL}$ for reducing power and $4.16 \mathrm{mg} / \mathrm{mL}$ for scavenging effect), while boiling water proved to be the most adequate solvent extracting a significantly $(p<0.05)$ higher amount of phenols in relation to total extracted olive constituents $(15.48 \mathrm{mg} / \mathrm{g}$ dry extract). Accordingly, the $\mathrm{EC}_{50}$ values obtained using the last conditions were significantly lower $(0.42 \mathrm{mg} / \mathrm{mL}$ for reducing power and $0.47 \mathrm{mg} / \mathrm{mL}$ for scavenging effect).

Fig. 1 shows the reducing power of "alcaparras" extracts obtained using both solvents at boiling and at rt, as a function of their concentration. The presence of reducers (i.e. antioxidants) caused the reduction of the $\mathrm{Fe}^{3+} /$ ferricyanide complex to the ferrous form $\left(\mathrm{Fe}^{2+}\right)$ monitored at $700 \mathrm{~nm}$.

The reducing power was found to increase with the amount of extract dissolved in the respective solvent. Aqueous extract obtained at $\mathrm{rt}$ showed the lowest reducing power values $(0.70$ at $5 \mathrm{mg} / \mathrm{mL})$. It must be emphasized that aqueous extracts obtained at boiling temperature presented the highest reducing power values $(1.10$ at $1 \mathrm{mg} /$ $\mathrm{mL}$ ). The extracts obtained using methanol at boiling and room temperature presented similar reducing power $(\sim 1.5$ at $5 \mathrm{mg} / \mathrm{mL}$ ). Despite the different extraction conditions, the "alcaparras" extracts reducing power was always higher than reducing power of BHA $(0.12$ at $3.6 \mathrm{mg} / \mathrm{mL})$ and $\alpha$-tocopherol $(0.13$ at $8.6 \mathrm{mg} / \mathrm{mL})$.

Antioxidant molecules can quench DPPH free radicals and convert them to a colourless/bleached product (i.e. 2,2diphenyl-1-hydrazine, or a substituted analogous hydrazine), resulting in a decrease in absorbance at $517 \mathrm{~nm}$. Free radical scavenging is one of the known mechanisms by which antioxidants inhibit lipid oxidation (Ferreres et al., 2006). The scavenging effect of "alcaparras" extracts obtained using both solvents at boiling and room temperatures was also examined (Fig. 2); results are expressed as the ratio percentage of the absorbance decrease of DPPH radical solution in the presence of extract at $517 \mathrm{~nm}$ to the absorbance of DPPH radical solution at the same wave length.

From the analysis of Fig. 2 we can observe that the extracts scavenging effects on DPPH radicals increase when the concentration increase. Once more, aqueous 
Table 1

Reducing power and scavenging effect $\mathrm{EC}_{50}$ values $(\mathrm{mg} / \mathrm{mL})$, and total phenols content (mg/g) of "alcaparras" table olives extracts obtained using different solvents and temperatures in the extractions ${ }^{\text {a }}$

\begin{tabular}{|c|c|c|c|c|}
\hline & bt $\mathrm{H}_{2} \mathrm{O}$ & $\mathrm{rt}_{2} \mathrm{O}$ & bt $\mathrm{MeOH}$ & rt $\mathrm{MeOH}$ \\
\hline Extraction yield (\%) & $7.20 \pm 0.25 b$ & $5.82 \pm 0.04 \mathrm{c}$ & $32.22 \pm 12.95 \mathrm{a}$ & $19.38 \pm 0.81 \mathrm{a}$ \\
\hline Total phenol content & $15.48 \pm 1.05 \mathrm{a}$ & $3.48 \pm 0.68 \mathrm{c}$ & $4.86 \pm 1.79 b$ & $5.90 \pm 0.21 b$ \\
\hline Reducing power $\left(\mathrm{EC}_{50}{ }^{\mathrm{b}}\right)$ & $0.42 \pm 0.03 c$ & $4.21 \pm 0.55 \mathrm{a}$ & $1.97 \pm 0.73 b$ & $1.51 \pm 0.13 b$ \\
\hline DPPH $\left(\mathrm{EC}_{50}{ }^{\mathrm{c}}\right)$ & $0.47 \pm 0.03 c$ & $4.16 \pm 1.04 \mathrm{a}$ & $1.55 \pm 0.52 b$ & $1.55 \pm 0.13 b$ \\
\hline
\end{tabular}

In each row different letters mean significant differences $(p<0.05)$ between different conditions. bt $\mathrm{H}_{2} \mathrm{O}-\mathrm{boiling}$ water; rt $\mathrm{H}_{2} \mathrm{O}-\mathrm{room}$ temperature water; bt $\mathrm{MeOH}$ - boiling methanol; rt $\mathrm{MeOH}$-room temperature methanol.

${ }^{\mathrm{a}}$ Each value is expressed as mean \pm standard deviation $(n=9)$.

${ }^{\mathrm{b}} \mathrm{EC}_{50}(\mathrm{mg} / \mathrm{mL})$ : effective concentration at which the absorbance is 0.5 .

${ }^{\mathrm{c}} \mathrm{EC}_{50}(\mathrm{mg} / \mathrm{mL})$ : effective concentration at which $50 \%$ of DPPH radicals are scavenged.

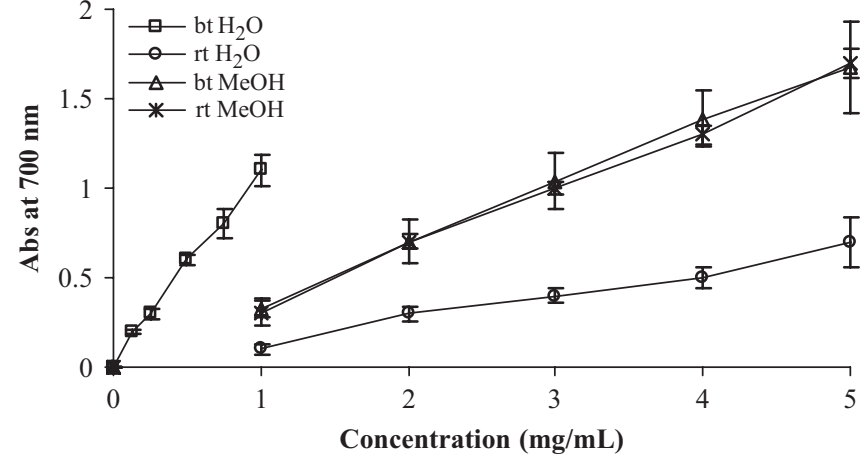

Fig. 1. Reducing power values of "alcaparras" table olives extracts obtained using water and methanol at boiling and room temperature. Each value is expressed as mean \pm standard deviation $(n=9)$. bt $\mathrm{H}_{2} \mathrm{O}$ boiling water; $\mathrm{rt} \mathrm{H}_{2} \mathrm{O}$-room temperature water; bt $\mathrm{MeOH}$-boiling methanol; rt $\mathrm{MeOH}$-room temperature methanol.

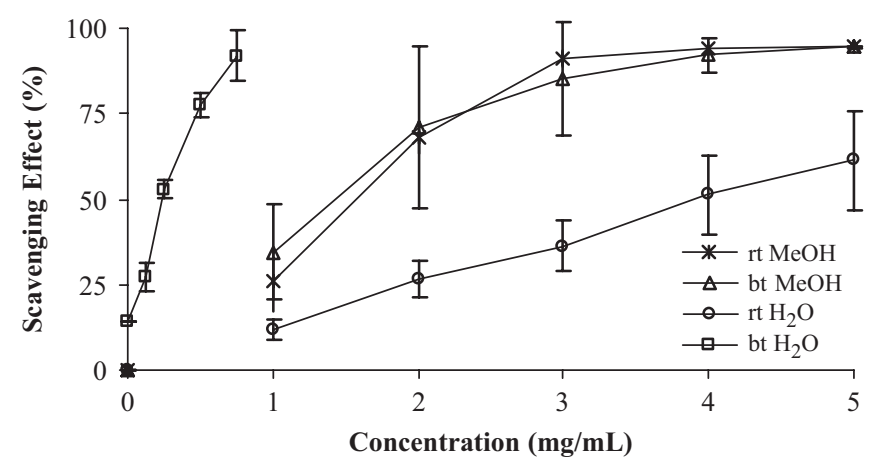

Fig. 2. Scavenging effect of "alcaparras" table olives extracts obtained using water and methanol at boiling and room temperature. Each value is expressed as mean \pm standard deviation $(n=9)$. bt $\mathrm{H}_{2} \mathrm{O}$ - boiling water; rt $\mathrm{H}_{2} \mathrm{O}$-room temperature water; bt $\mathrm{MeOH}$-boiling methanol; rt $\mathrm{MeOH}$-room temperature methanol.

extract obtained at boiling temperature scavenged DPPH radicals more effectively $(92.0 \%$ at $1 \mathrm{mg} / \mathrm{mL})$ than aqueous extract obtained at $\mathrm{rt}(61.3 \%$ at $5 \mathrm{mg} / \mathrm{mL})$. The extracts obtained using methanol at boiling and room temperature presented the same scavenging effect $(94.6 \%$ at $5 \mathrm{mg} / \mathrm{mL})$. These values were comparable to the scavenging effect obtained for the standards BHA $(96 \%$ at $3.6 \mathrm{mg} / \mathrm{mL})$ and $\alpha$-tocopherol (95\% at $8.6 \mathrm{mg} / \mathrm{mL})$.

In our study, water at boiling temperature was the most effective solvent for the antioxidants extraction, providing higher total phenol content, and therefore a higher antioxidant potential. Previous studies on the influence of different extracting solvents in the yield of phenols extracted from other plant materials and in antioxidant activity of the extracts obtained have been reported (Cheung, Peter, \& Vincent, 2003; Sun \& Ho, 2005). Nevertheless, our results were not in agreement with that of the above mentioned authors who observed a better scavenging activity and higher phenolic content in methanolic or acetone extracts.

\subsection{Antioxidant potential of several "alcaparras" samples}

The most efficient conditions for the phenols extraction (boiling water) were applied to 10 stoned table olives "alcaparras" from the traditional market. Table 2 shows the reducing power and scavenging effect $\mathrm{EC}_{50}$ values $(\mathrm{mg} /$ $\mathrm{mL}$ ), and total phenol content $(\mathrm{mg} / \mathrm{g}$ dry extract) of the extracts obtained from 10 olive samples.

$\mathrm{EC}_{50}$ values obtained for both methods were lower than $1.8 \mathrm{mg} / \mathrm{mL}$, and in the order of $\mathrm{CA} 2<\mathrm{B} 1<\mathrm{MC}<\mathrm{B} 4<$ $\mathrm{M} 2<\mathrm{B} 2<\mathrm{B} 5 \sim \mathrm{CA} 1<\mathrm{B} 3<\mathrm{M} 1$. The extract of sample CA2 (from Carrazeda de Ansiães) showed the highest phenolic content $(29.88 \mathrm{mg} / \mathrm{g})$ and the highest antioxidant potential, presenting the lowest $\mathrm{EC}_{50}$ values $(0.36 \mathrm{mg} / \mathrm{mL}$ for reducing power and $0.34 \mathrm{mg} / \mathrm{mL}$ for scavenging effect). Otherwise, the extract of sample M1 (from Mirandela) showed the lowest phenolic content $(5.58 \mathrm{mg} / \mathrm{g})$ and the highest $\mathrm{EC}_{50}$ values $(1.64 \mathrm{mg} / \mathrm{mL}$ for reducing power and $1.72 \mathrm{mg} /$ $\mathrm{mL}$ for scavenging effect). The "alcaparras" table olive consumption needed for the intake of phenols in order to achieve the same antioxidant capacity depends on the sample used. For example, if we choose two samples bought in the same municipality (CA1 and CA2) to reach the same antioxidant capacity it is necessary to consume three times more olives from the sample CA1 than from the sample CA2. This fact is probably related to the olive variety used to make "alcaparras". It is known that in the 
Table 2

Reducing power and scavenging effect $\mathrm{EC}_{50}$ values $(\mathrm{mg} / \mathrm{mL})$, and total phenol content (mg/g) of 10 different "alcaparras" table olives samples

\begin{tabular}{|c|c|c|c|c|c|c|c|c|c|c|c|}
\hline \multirow[t]{2}{*}{ Samples } & \multirow{2}{*}{$\begin{array}{l}\text { Total phenol } \\
\text { content }\end{array}$} & \multicolumn{5}{|c|}{ Reducing power $\left(\mathrm{EC}_{50}\right)$} & \multicolumn{5}{|l|}{$\mathrm{DPPH}\left(\mathrm{EC}_{50}\right)$} \\
\hline & & Experimental & Polynomial & $\begin{array}{l}\text { Error } \\
(\%)\end{array}$ & Linear & $\begin{array}{l}\text { Error } \\
(\%)\end{array}$ & Experimental & Polynomial & $\begin{array}{l}\text { Error } \\
(\%)\end{array}$ & Linear & $\begin{array}{l}\text { Error } \\
(\%)\end{array}$ \\
\hline Bragança (B1) & 16.63 & 0.49 & 0.39 & 20 & 0.66 & 36 & 0.40 & 0.30 & 25 & 0.64 & 60 \\
\hline Bragança (B2) & 9.54 & 0.88 & 0.96 & 9 & 1.00 & 13 & 0.89 & 0.97 & 9 & 1.02 & 14 \\
\hline Bragança (B3) & 6.58 & 1.40 & 1.30 & 6 & 1.14 & 18 & 1.71 & 1.40 & 18 & 1.18 & 31 \\
\hline Bragança (B4) & 14.59 & 0.58 & 0.52 & 11 & 0.76 & 31 & 0.42 & 0.44 & 6 & 0.75 & 79 \\
\hline Bragança (B5) & 7.51 & 0.97 & 1.19 & 23 & 1.09 & 13 & 0.93 & 1.25 & 35 & 1.13 & 22 \\
\hline Mirandela (M1) & 5.58 & 1.64 & 1.44 & 12 & 1.18 & 28 & 1.72 & 1.56 & 10 & 1.23 & 29 \\
\hline Mirandela (M2) & 11.90 & 0.59 & 0.73 & 24 & 0.89 & 51 & 0.65 & 0.69 & 7 & 0.89 & 38 \\
\hline $\begin{array}{l}\text { Mac Cavaleiros } \\
(\mathrm{MC})\end{array}$ & 16.00 & 0.51 & 0.43 & 15 & 0.69 & 13 & 0.44 & 0.34 & 22 & 0.67 & 53 \\
\hline $\begin{array}{l}\text { Car. Ansiães } \\
\text { (CA1) }\end{array}$ & 7.51 & 1.15 & 1.19 & 4 & 1.09 & 5 & 1.07 & 1.25 & 17 & 1.13 & 6 \\
\hline $\begin{array}{l}\text { Car. Ansiães } \\
\text { (CA2) }\end{array}$ & 29.88 & 0.36 & 0.37 & 2 & 0.04 & 88 & 0.34 & 0.37 & 9 & 0.08 & 76 \\
\hline
\end{tabular}

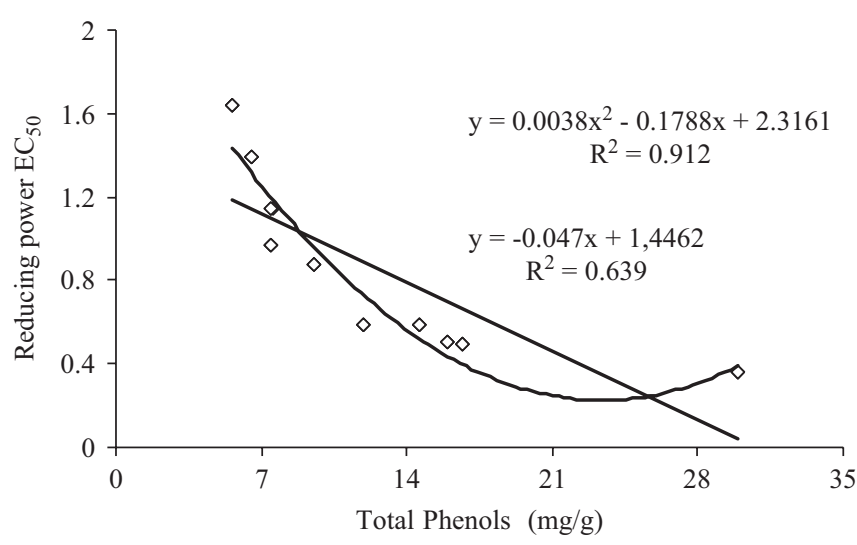

Fig. 3. Correlation established between total phenol content and reducing power values.

Northeast of Portugal the olive varieties have different fatty acids profiles, different levels of monounsaturated fatty acids (especially oleic acid) (Pereira, Casal, Bento, \& Oliveira, 2002; Pereira, Oliveira, Casal, \& Alves, 2002) and different phenol profile (Vinha et al., 2005) which is related to its antioxidant properties (Owen et al., 2000; CarrascoPancorbo et al., 2005). The olive ripening is also a factor that could have influence in the antioxidant potential. During the olive maturation, some changes occur in the fruit composition, especially on the polyphenols: oleuropein decreases and tyrosol and hydroxytyrosol increase (Gutiérrez, Jímenez, Ruíz, \& Albi, 1999; Salvador, Aranda, \& Fregapane, 2001; Skevin et al., 2003; Beltrán, Aguilera, Del Rio, Sanchez, \& Martinez, 2005).

A significantly negative linear correlation was established between phenol content and $\mathrm{EC}_{50}$ reducing power values (determination coefficients $0.639 ; p<0.001$ ) (Fig. 3). This negative linear correlation proves that the sample with highest total phenol content shows higher reducing power and lower $\mathrm{EC}_{50}$ values (sample CA2), while the sample

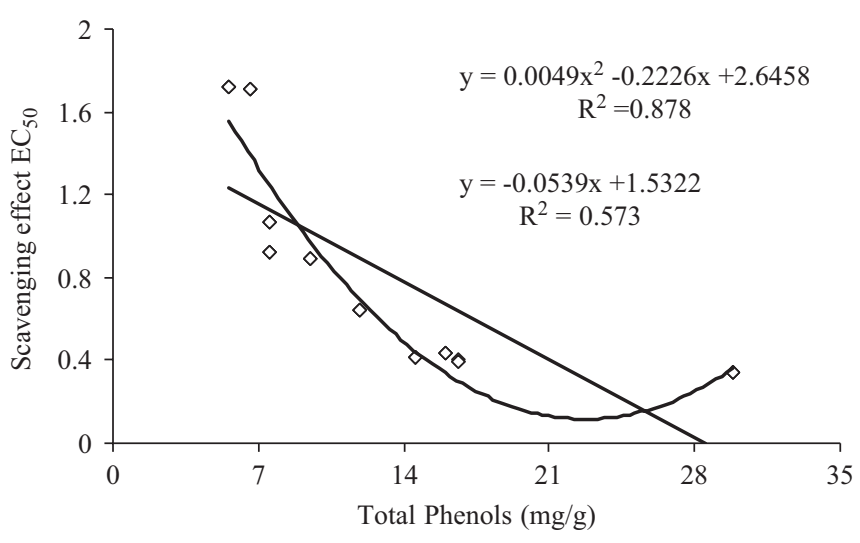

Fig. 4. Correlation established between total phenol content and scavenging effect.

with lowest total phenol content presents lower reducing power and higher $\mathrm{EC}_{50}$ values (sample M1). A similar situation was observed when we established a correlation between the total phenol content and scavenging effect values (determination coefficients $0.573 ; p<0.001$ ) (Fig. 4). The obtained data were also adjusted to a polynomial curve (Figs. 3 and 4) which gave a better approximation, with $r^{2}$ of 0.912 and 0.878 for reducing power and DPPH radical scavenging effect $\mathrm{EC}_{50}$ values, respectively. On the basis of the previously established relationships between $\mathrm{EC}_{50}$ values and total phenol, the $\mathrm{EC}_{50}$ values were estimated according polynomial and linear curves (Table 2), and compared to experimental values through the error percentage. As can be observed, the values were similar and the error found was, in most cases, less than $10 \%$, being lower in the case of polynomial approximation. This information is particularly useful when the total phenol content is known because it allows the estimation of $\mathrm{EC}_{50}$ values instead of their experimental determination. 
In conclusion, extraction with water at boiling temperature proved to be a better method to extract phenolic antioxidant compounds from "alcaparras" table olives, than methanol at room or boiling temperature. A significantly negative linear regression was established between the total phenol content found in the samples and its antioxidant activity (reducing power and radical scavenging effect on DPPH radicals).

The results obtained in the present work denote that stoned table olives "alcaparras" may constitute a good source of healthy compounds or phenols intake in the diet, suggesting that it could be useful in the prevention of diseases in which free radicals are implicated. In addition, and as far as we know, this is the first report considering the antioxidant potential of "alcaparras" table olives; furthers studies are need to clarify the role of different olive cultivars and their ripening stage used to make "alcaparras" table olives in its phenolic composition and antioxidant potential.

\section{Acknowledgement}

The authors are grateful to INTERREG III A Program, Project MOABEPE for financial support of this work.

\section{References}

Beltrán, G., Aguilera, M. P., Del Rio, C., Sanchez, S., \& Martinez, L. (2005). Influence of fruit ripening process on the natural antioxidant content of Hojiblanca virgin olive oils. Food Chemistry, 89, 207-215.

Blekas, G., Vassilakis, C., Harizanis, C., Tsimidou, M., \& Boskou, D. G. (2002). Biophenols in table olives. Journal of Agriculture and Food Chemistry, 50, 3688-3692.

Boskou, G., Salta, F. N., Chrysostomou, S., Mylona, A., Chiou, A., \& Andrikopoulos, N. K. (2006). Antioxidant capacity and phenolic profile of table olives from the Greek market. Food Chemistry, 94 $558-564$

Bouaziz, M., \& Sayadi, S. (2005). Isolation and evaluation of antioxidants from leaves of a Tunisian cultivar olive tree. European Journal of Lipid Science and Technology, 107, 497-504.

Briante, R., Patumi, M., Terenziani, S., Bismuto, E., Febbraio, F., \& Nucci, R. (2002). Olea europaea L. leaf extract and derivatives: Antioxidant properties. Journal of Agriculture and Food Chemistry, 50, 4934-4940.

Carrasco-Pancorbo, A., Cerretani, L., Bendini, A., Segura-Carretero, A., Carlo, M., Gallina-Toschi, T., et al. (2005). Evaluation of the antioxidant capacity of individual phenolic compounds in virgin olive oil. Journal of Agriculture and Food Chemistry, 53, 8918-8925.

Cheung, L. M., Peter, C. K., \& Vincent, E. C. (2003). Antioxidant activity and total phenolics of edible mushroom extracts. Food Chemistry, 81, 249-255.

Ferreira, I. C. F. R., Barros, L., Soares, M. E., Bastos, M. L., \& Pereira, J A. (2007). Antioxidant activity and phenolic contents of Olea europaea L. leaves sprayed with different copper formulations. Food Chemistry, 103, 188-195.

Ferreres, F., Sousa, C., Vrchovska, V., Valentão, P., Pereira, J. A., Seabra, R. M., et al. (2006). Chemical composition and antioxidant activity of tronchuda cabbage internal leaves. European Food Research and Technology, 222, 88-98.

Fukushima, N. S., \& Tsuda, H. (1985). Carcinogenity and modification of the carcinogenic response by BHA, BHT and other antioxidants. Critical Reviews in Toxicology, 15, 109-150.
Gordon, M. H., Paiva-Martins, F., \& Almeida, M. (2001). Antioxidant activity of hydroxytyrosol acetate compared with that of other olive oil polyphenols. Journal of Agriculture and Food Chemistry, 49, 2480-2485.

Gutiérrez, F., Jímenez, B., Ruíz, A., \& Albi, M. A. (1999). Effect of olive ripeness on the oxidative stability of virgin olive oil extracted from the varieties Picual and Hojiblanca and on the different components involved. Journal of Agriculture and Food Chemistry, 47, 121-127.

Halliwell, B. (1997). Antioxidants in human health and disease. Annual Review of Nutrition, 16, 33-50.

Halliwell, B., \& Gutteridge, J. M. C. (1999). Free radicals in biology and medicine. Oxford University Press: United Kingdom.

Hatano, T., Kagawa, H., Yasuhara, T., \& Okuda, T. (1988). Two new flavonoids and other constituents in licorice root: Their relative astringency and radical scavenging effects. Chemical and Pharmaceutical Bulletin, 36, 2090-2097.

Keys, A. (1995). Mediterranean diet and public health: Personal reflections. American Journal of Clinical Nutrition, 61, 1321S-1323S.

Marsilio, V., Campestre, C., \& Lanza, B. (2001). Phenolic compounds change during California-style ripe olive processing. Food Chemistry, 74, 55-60

Meirinhos, J., Silva, B. M., Valentão, P., Seabra, R. M., Pereira, J. A., Dias, A., et al. (2005). Analysis and quantification of flavonoidic compounds from Portuguese olive (Olea europaea L.) leaf cultivars. Natural Product Research, 19, 189-195.

Owen, R. W., Haubner, R., Mier, W., Giacosa, A., Hull, W. E., Spiegelhalder, B., et al. (2003). Isolation, structure and antioxidant potential of the major phenolic and flavonoid compounds in brined olive drupes. Food and Chemical Toxicology, 41, 703-717.

Owen, R. W., Mier, W., Giacosa, A., Hull, W. E., Spielgelhalder, B., \& Bartsch, H. (2000). Phenolic compounds and squalene in olive oils: The concentration and antioxidant potential of total phenols, simple phenols, secoiridoids, lignans and squalene. Food Chemistry Toxicology, 38, 647-659.

Oyaizu, M. (1986). Studies on products of browning reactions: Antioxidative activities of products of browning reaction prepared from glucosamine. Japanese Journal of Nutrition, 44, 307-315.

Paiva-Martins, F., Gordon, M. H., \& Gameiro, P. (2003). Activity and location of olive oil phenolic antioxidants in liposomes. Chemistry and Physics of Lipids, 124, 23-36.

Panagiotakos, D. B., Pitsavos, C., \& Stefanadis, C. (2006). Dietary patterns: A Mediterranean diet score and its relation to clinical and biological markers of cardiovascular disease risk. Nutrition, Metabolism and Cardiovascular Diseases, 16, 559-568.

Pereira, J. A., Casal, S., Bento, A., \& Oliveira, M. B. P. P. (2002). Influence of the olive storage period on oil quality in the Portuguese "Cobrançosa," "Madural" and "Verdeal Transmontana" cultivars. Journal of Agriculture and Food Chemistry, 50, 6335-6340.

Pereira, J. A., Oliveira, M. B. P. P., Casal, S., \& Alves, M. R. (2002). Discrimination of varietal olive oils of the portuguese cultivars Cobrançosa, Madural and Verdeal based on their fatty acids composition. Acta Horticulturae, 586, 591-594.

Pereira, J. A., Pereira, A. P., Ferreira, I. C. F. R., Valentão, P., Andrade, P., Seabra, R., et al. (2006). Phenolics compounds, antioxidant potential and microbial activity of table olives from Portugal. Journal of Agriculture and Food Chemistry, 54, 8425-8431.

Ranalli, A., Contento, S., Lucera, L., Febo, M. D., Marchegiani, D., \& Fonzo, V. D. (2006). Factors affecting the contents of Iridoid Oleuropein in olive leaves (Olea europaea L.). Journal of Agriculture and Food Chemistry, 54, 434-440.

Romero, C., Brenes, M., Yousfi, K., García, P., García, A., \& Garrido, A. (2004). Effect of cultivar and processing method on the contents of polyphenols in table olives. Journal of Agriculture and Food Chemistry, $52,479-484$.

Romero, C., García, P., Brenes, M., García, A., \& Garrido, A. (2002). Phenolic compounds in natural black Spanish olive varieties. European Food Research Technology, 215, 489-496. 
Salvador, M. D., Aranda, F., \& Fregapane, G. (2001). Influence of fruit ripening on "Cornicabra" virgin olive oil quality. A study of four successive crop seasons. Food Chemistry, 73, 45-53.

Singleton, V. L., \& Rossi, J. A., Jr. (1965). Colorimetric of total phenolics with phosphomolybdic-phosphotungstic acid reagents. American Journal of Enology and Viticulture, 16, 144-158.

Skevin, D., Rade, D., Strucelj, D., Mokrovcak, Z., Nederal, S., \& Bencic, D. (2003). The influence of variety and harvest time on the bitterness and phenolic compounds of olive oil. European Journal of Lipid Sciences and Technology, 105, 536-541.

Sousa, A., Ferreira, I. C. F. R., Calhelha, R. C., Andrade, P. B., Valentão, P., Seabra, R., et al. (2006). Phenolics and antimicrobial activity of traditional stoned table olives "alcaparra". Bioorganic and Medicinal Chemistry, 14, 8533-8538.
Stone, W. L., Leclair, I., Ponder, T., Bagss, G., \& Barret-Reis, B. (2003). Infants discriminate between natural and synthetic vitamin E. American Journal of Clinical Nutrition, 77, 899-906.

Sun, T., \& Ho, C. T. (2005). Antioxidant activities of buckwheat extracts. Food Chemistry, 90, 743-749.

Trichopoulou, A., \& Lagiou, P. (1997). Healthy traditional Mediterranean diet: An expression of culture, history and lifestyle. Nutrition Reviews, 55, 383-389.

Vinha, A. F., Ferreres, F., Silva, B. M., Valentão, P., Gonçalves, A., Pereira, J. A., et al. (2005). Phenolic profiles of Portuguese olive fruits (Olea europaea L.): Influence of cultivar and geographical origin. Food Chemistry, 89, 561-568. 